\title{
Considerations for Providing Etymological Information in the Advanced Ndebele Dictionary*
}

Langa Khumalo, African Languages Research Institute (ALRI), University of Zimbabwe, Harare, Zimbabwe (la_nga@yahoo.co.uk)

\begin{abstract}
This article discusses the presentation of etymological information in the prospective Advanced Ndebele Dictionary (henceforth the AND) which is still in its planning stage. The AND will be a successor to Isichazamazwi SesiNdebele (henceforth the ISN), a medium-sized, general-purpose, monolingual Ndebele dictionary published in 2001. The AND will not just be larger than the ISN, but will be more advanced with regard to the depth and scope of its lexical items and definitions. Whereas the ISN was based on a corpus size of about a million running words, the AND is envisaged to have as basis a corpus size of about five million. To this end, corpus expansion is an ongoing process. Again, unlike its forerunner, the AND will provide additional grammatical information for each lexical item, including phonetic transcription, tone marking and etymology. It is the inclusion of etymological information in the AND that is critically examined in this article. There is a long tradition of providing etymological information in modern dictionaries from Oxford's New English Dictionary to ALRI's Duramazwi Guru reChiShona.
\end{abstract}

Keywords: ETYMOLOGY, ADVANCED NDEBELE DICTIONARY, CULTURE, HERITAGE, LANGUAGE CONTACT

Opsomming: Oorwegings vir die verskaffing van etimologiese inligting in die Gevorderde Ndebelewoordeboek. Hierdie artikel bespreek die aanbieding van etimologiese inligting in die toekomstige Gevorderde Ndebelewoordeboek (voortaan die GNW) wat nog in sy beplanningstadium is. Die GNW sal 'n opvolger wees van die Isichazamazwi SesiNdebele (voortaan die ISN), 'n middelgroot, meerdoelige, eentalige Ndebelewoordeboek wat in 2001 gepubliseer is. Die GNW sal nie net groter as die ISN wees nie, maar sal meer gevorderd wees wat betref die diepte en omvang van sy leksikale items en definisies. Waar die ISN gebaseer was op 'n korpusgrootte van ongeveer 'n miljoen woordoptekeninge, word voorsien dat die GNW 'n korpusgrootte van ongeveer vyf miljoen as basis sal hê. Vir hierdie doel is korpusuitbreiding 'n voortgaande proses. Weer eens, anders as sy voorloper, sal die GNW bykomende grammatiese inligting oor elke leksikale item verskaf, insluitende fonetiese transkripsie, toonaanduiding en etimologie. Dit is die insluiting van etimologiese inligting in die GNW wat in hierdie artikel krities beskou word. Daar is 'n lang tradisie vir die verskaffing van etimologiese inligting in moderne woordeboeke vanaf Oxford se New English Dictionary tot ALRI se Duramazwi Guru reChiShona.

* This article was presented as a paper at the Tenth International Conference of the African Association for Lexicography, organised by the Sesiu sa Sesotho Lexicography Unit, University of the Free State, Bloemfontein, Republic of South Africa, 13-15 July 2005.

Lexikos 17 (AFRILEX-reeks/series 17: 2007) 307-315 
Sleutelwoorde: ETIMOLOGIE, GEVORDERDE NDEBELEWOORDEBOEK, KULTUUR, ERFENIS, TAALKONTAK

\section{Introduction}

This article consists of two main parts. In the first part, it will be argued that, except for its interest to the target users of the prospective Advanced Ndebele Dictionary (henceforth the AND), etymological information is often valuable as an accompaniment to historical and cultural research. Ndebele shares its heritage with other Nguni languages spoken in South Africa, of which all drew much from contact with English and Afrikaans. Etymological information is valuable, especially for a language like Ndebele that has not been extensively documented. In the second part, challenges with regard to etymological information will be discussed. Historical changes in meaning are an inevitable fact, but are sometimes decried as if language ought to be arrested at some period in time. Consequentially an attempt to fix meanings or to tie words to their "original" meanings is denying the social reality of linguistic usage. A classic example of the lawyer who disputed a witness's use of the word hysterical, is told by Warburg (1968: 351-352).

Furthermore, it will be argued that older senses of some words sometimes survive in limited contexts, while the most frequent meaning has changed. As a result, this presents the problem whether to provide such etymological information. Then occasionally there are also erroneous origins that have become enshrined in the language through the process of "folk etymology" by which the pronunciation or spelling of a word is modified on a false analogy. Although it hardly needs to be argued that modern lexicographers try to avoid speculation and guesswork, only giving information based on thorough research, instances such as these have occurred in Ndebele. Finally it will be argued that the historical information can be interesting and instructive, although not all of it is accessible and relevant. The history of a word is not necessarily its meaning.

\section{Background}

The background of the Ndebele people has recently been related in a number of works, which include Hadebe et al. (2001), Hadebe (2002), and Khumalo (2003). What follows is a brief synopsis. Around 1820, the Ndebele people broke away from the then mighty Zulu kingdom, in the present-day KwaZuluNatal province of South Africa. The original group that left Zululand was initially called the Khumalos as their leader, Mzilikazi, was from the Khumalo clan. Mzilikazi and his Khumalos, as they were known then, moved northwards from Zululand into Sotho territory in the present-day Gauteng province of South Africa. Mzilikazi assimilated a number of Sotho people who soon out- 
numbered the original Khumalos who were of Nguni origin. Consequently the group ceased to be referred to as the Khumalos. The Sotho called all raiding Nguni groups kiMatebele, which is thought to be the origin of the name Ndebele. Around 1838-1840, the Ndebele people settled in the southern part of presentday Zimbabwe. Mzilikazi continued to expand his nation by raiding many tribes, incorporating them into his political system. It is in Zimbabwe that the Ndebele people assimilated by far the largest number of people. These mainly included the Nyubi, Kalanga, Nanzwa, Nambya, to some extent the Tonga and a number of Shona tribes. Most of these were previously under rulers known as the Mambo. In 1896, the Ndebele people came under British rule, exposed to yet another language, English, and the technological advancement it brought with it. This scenario presented an environment for language contact and inevitably language change (Khumalo 2003: 2). The challenge in tracing etymological information would be to correctly document this expansive language contact scenario.

\section{Value and Role of Etymology}

Landau (2001: 127) writes that people mostly find dictionaries fascinating, particularly the derivation of words presented in them. Etymology is therefore viewed as attracting attention in a dictionary, providing interesting background information about lexical items. From the literature, it is clear that, although dictionary users most often search for meaning, meaning does not have the same distinction as etymology, which combines knowledge of other languages with scholarship, which reveals hidden relationships.

An example to illustrate this observation is the Ndebele word uMantshingelane (a guard). The etymology of this word is the English verb phrase marching on the line, which is one of the drills the guards perform during their inspection. The word was adapted by breaking up the English sequence, unusual in Ndebele, to form the normal Ndebele sequence, a process that can be presented as follows:

$$
\begin{array}{cccc}
\text { word } / \text { phrase } & \rightarrow & > & \text { new word } \\
(\text { from language } \mathrm{X}) & (\text { decomposition }) & (\text { reconstruction }) & (\text { in language } \mathrm{Y})^{1}
\end{array}
$$

The decomposition and reconstruction of the word so that it conforms to the phonological rules of the borrowing language can loosely be referred to as phonologizing the new word, the process by which uMantshingelane was adapted from English as illustrated below:

$$
\begin{array}{lll}
\text { English verb phrase } & & \text { Ndebele noun } \\
\text { marching on the line } & \rightarrow \quad>\quad \text { uMantshingelane }
\end{array}
$$

It is also clear from this example that the chief value of etymology lies not only in its historical, but also in its linguistic interest. It suggests curiosity about, if 
not familiarity with, the study of classical languages, proto-languages or elements of comparative philology (Landau 2001: 131-132).

In the literature, there have been arguments about the usefulness of etymologies. It has been suggested that etymologies should be omitted altogether from non-historical general dictionaries. What then is the role of etymology?

Firstly: Etymological information can provide raw material for the scholar and the student studying the history of a language. To this end, data are provided that lead to further inquiry into a people's history. For example, the etymological information on the word Ndebele provides such material. As has been stated above, Mzilikazi had contact with the Sotho with the result that the group ceased to be referred to as the Khumalos. The Sotho referred to all raiding Nguni groups as kiMatebele (meaning 'warriors with long shields'), hence the name Matebele for the Ndebele (Hughes and Van Velsen 1954: 42), which in Nguni became amaNdebele. Nyathi (1994: 24) on the other hand claims that the name Matebele derives from the Sotho verb hotebela, "okutsho ukubhidliza, ukubulala kumbe ukuchitha", meaning 'to destroy, kill or ruin'. In early missionary writings, the Ndebele are often referred to as the Matabele. It seems the term Matabele had been applied to another Nguni group, the Hlubi, long before it was used to designate the present-day Zimbabwean Ndebele people (Dube 1993: 3). It can therefore be concluded that the actual meaning of Matebele remains unresolved.

If it is accepted that the name Ndebele was derived from Matebele, in historical and linguistic studies on Ndebele, it is still a controversy how it happened. It should be noted that in present-day South Africa there is another Nguni group also called Ndebele. It is believed that this group left Zululand much earlier and was given the name long before Mzilikazi's group. Rasmussen (1977: 162) writes:

Eventually the name 'Matabele', or 'Ndebele' in its Anglo/Nguni form, came to apply only to Mzilikazi's people and to the 'Transvaal Ndebele'. These latter were the descendants of much earlier Nguni immigrants onto the highveld. Mzilikazi had dealings with some of these communities during the 1820s; however, his people and the Transvaal Ndebele are essentially unrelated.

This information provides material for someone studying the history of the language.

Secondly: Etymological information increases the understanding of and simultaneously stimulates interest both in language in general and in one language in particular. While certain words may be taken for granted because they mean what society has come to accept, etymological information brings an interesting account of how that meaning was arrived at. For example, the etymological information of the word umfundisi (reverend and/or teacher) provides such an exposition. Education was introduced to the Ndebele by the missionaries who preached as well as taught in their newly-established schools. The preacher, who taught the scriptural lessons and church hymns to the Nde- 
bele converts was also a "linguist", who developed orthographies for the then unwritten language, hence he was seen as a school teacher as well. The word umfundisi is derived from the verb -fundisa (to teach). When the colonial government in Rhodesia began to build schools for Africans in the 1960s, teachers who were not necessarily preachers, were hired. Today, there is no longer an obvious link between education and the church in Zimbabwe, teachers being seen as independent of the clergy. The word umfundisi has now narrowed its meaning, referring to a preacher only. At present a teacher is called umbalisi, derived from -balisa 'to help to read' (Hadebe 2002: 126). Interestingly though, 'The boy is reading a book' is rendered in Zulu as Umfana ufunda incwadi, distinct from Ndebele Umfana ubala ugwalo. Having narrowed the sense of umfundisi, Ndebele uses the verb -funda with the meaning 'to learn'.

Thirdly: Since a dictionary is a record of the culture of the speakers of the language it describes, etymological information also provides clues to the history of a specific culture and its relationship to other cultures. Etymological information of words like uMlimu (God) and Ndebele surnames Mdlongwa, Dawu and Mnkandla provide evidence of the historical relationship between the Ndebeles (then known as the Khumalos) and the Sotho. As has been stated above, when the Khumalo clan left Zululand, it had contact with other tribal groups. Between 1822 and 1837, the Ndebeles sojourned in the present-day Gauteng province in South Africa. One event associated with the stay in the then Transvaal region was contact with the missionaries. The London Missionary Society had established a mission station at Kuruman among the Tlaping. Although the Ndebeles did not generally accept the Christian faith, some Sotho words from the religious realm found their way into the Ndebele language, for example, the Sotho name Modimo in its Ndebele adoptive form $u M l i m u^{2}$, the equivalent of English God. Although uMlimu does not semantically capture God's greatness in the same way as uNkulunkulu (literally the Great Great One), it has found its place in the Ndebele lexicon, its etymology being understood within this cross-cultural context. Furthermore, the Sotho people, who were incorporated into the fast-growing Ndebele empire abandoned their language in preference to Ndebele. Even their tribal names were changed in conformance with the phonological structure of the Ndebele language, for instance, the Sotho names Motlokwa, Tau and Mokgatla became Mdlongwa, Dawu and Mnkandla ${ }^{3}$ respectively. It is clear that change, which was inevitable, favoured the dominating tribe (Khumalo 2004: 4).

The Ndebeles have always viewed themselves in many ways similar to the Zulus, arguments sometimes being put forward that these groups belong to one and the same people. According to Hadebe (2002: 129), there are many words assumed to be derived from Zulu, yet actually Zulu adopted them from Afrikaans, thereby becoming part of the Ndebele vocabulary. Lexical etymology of some of the words include isitulo (chair) from Afrikaans stoel, ibhatshi (jacket) from Afrikaans baadjie, ijazi (coat) from Afrikaans jas, umfolo (furrow) from Afrikaans voor and umjaho (chase) from Afrikaans jaag. Hadebe (2002: 129) 
observes that in the 1970s, there was a period when loanwords from English were avoided in Ndebele. This period of purism saw the substitution of loanwords from English by words believed to be indigenous as they were taken from Zulu to which most Ndebele speakers look as the source of indigenous vocabulary. It is unfortunate that this purism did not purge Ndebele of European loanwords as intended, but substituted English for Afrikaans as the source language. This does not mean that Ndebele speakers preferred Afrikaans to English, but that they adopted these Afrikaans words via Zulu believing them to be indigenous Zulu words. The cause for these Afrikaans adoptions was the contact of the Zulu people with the Afrikaners. More importantly, the etymology of these words is based on a speculative and erroneous perception. This also causes semantic problems to arise. For instance, the meaning of umjaho is 'competition' in Zulu and Ndebele, but etymologically the word jaag means 'chase' in Afrikaans from which it is derived.

There are also examples which demonstrate cultural contact. One of the greatest changes to the Ndebele language was brought about after the arrival of the Ndebeles in Zimbabwe. As stated above, this was the time when they came into contact with the Nyubi, Kalanga, Nanzwa, Nambya, to some extent the Tonga and a number of Shona tribes. The honorific plural or pronouns of power are one example of Shona lingual influence on the Ndebele language. Among the Shona people, when an older person or a person in a senior social position is addressed, an honorific plural is used. The Ndebele language has embraced this concept by adding the plural morpheme /-li/ as demonstrated by the following two examples:

(1) sakubona? how do you do? (singular)

*salibonani? how do you do? (plural) [derived from Shona mhoroi, which denotes plural]

(2) kunjani? how are you? (singular)

*linjani? how are you? (plural) [derived from Shona makadii, which denotes plural]

Another form of change that has occurred in the Ndebele language is in its verbal morphology as can be seen from the etymology of the words umile (he/she is standing) and hambisa (hurry up). The etymology of these two words can also be explained by historical cultural contact. The form umi (he/she is standing) has been changed to *umile (derived from Shona amire) by adding the extension $-i l e^{4}$ to the verb stem umi. The verb tshitsha (hurry) now has an equivalent * hambisa (derived from Shona fambisa). ${ }^{5}$ The Shona word for hurry up is fambisa, derived from the verb famba (walk) by adding an extension -isa. The Ndebele language has derived a new word, meaning 'hurry up', from the verb hamba (walk) by adding an extension -isa to derive the verb hambisa.

The conclusion can be drawn from the above that to include entries without etymology in a dictionary is to divorce the language from its past. Further- 
more, by doing this, the opportunity is missed to show language in its context, notwithstanding the fact that words without etymology may be very well defined. A dictionary should give users the opportunity to expand their view of the language by offering more information than is necessary, even though some users might have difficulty understanding this. Etymologies demonstrate that language changes in form and meaning. They remind users of the way other cultures, or their own, viewed particular words in the past. Hence, etymology forms an important component of a dictionary.

\section{Problems and Challenges of Providing Etymological Information}

While etymological information may be viewed as valuable in its own right, it is often argued that it tells users little about the current meaning of words and is in fact often misleading. The error of associating present meaning with past etymological meaning is commonplace, also in the sciences, particularly medicine (Landau 2001: 128). Manuila (1981), quoted by Landau, points out: "Many words, whether technical or in ordinary use, have departed so widely from their original meaning that the latter can be of interest only to medical historians and linguists."

Another argument against the inclusion of etymological information is that users interested in etymology regard etymologies as stories about word histories. Furthermore, and more importantly, the conventional dictionary treatment of etymologies usually does not shed much light on the semantic development of words, for two reasons:

(a) As there has often been too little scholarly research, there is uncertainty or ignorance about many etymologies.

(b) Because dictionaries have better uses for the space, their etymologies have usually been compressed as much as possible.

One challenge facing a lexicographer when planning to include etymological information in a dictionary like the AND, is first to look at the type of product aimed at, and then to consider the primary target users of this product. The AND is a successor to Isichazamazwi SesiNdebele (henceforth the ISN), a monolingual dictionary with 20010 headwords targeted mainly at secondary school users. The primary target users of the AND will be mainly tertiary institutions, including high schools, colleges and universities. These form a group whose research is more investigative and more profound in disciplines such as language and history. It should be considered whether it would have positive value to give etymological information in a dictionary targeted at this group. The editors have decided to include etymological information, primarily because they recognise that a dictionary is a cultural repository in which information on the origin of words is an accompaniment to linguistic and historical research. 
Planning is one challenge and implementing or executing the plan is another. A dictionary has to balance both detail and space. To this end, one of the challenges is the extent to which the editors have space to include the etymological detail of each word. The information should be detailed enough to give full scope to the value of etymology, but at the same time remain balanced with respect to space. The question the editors should constantly consider is how much etymological detail should be included in the AND.

Another challenge pertains to the documentation of the language. Ndebele has not been extensively recorded. It is only recently that some works on Ndebele have been published, including the ISN, its first monolingual dictionary which appeared in 2001. The challenge therefore is how much historical facts and details can possibly be found for a language like Ndebele which is not well documented. This is in the light of the existing scepticism about oral tradition which is steeped in myths.

The solution to this challenge is that enough time should be allowed the editors for research to verify facts and details. Planning should be well in advance to give the editors enough time for doing research. Consequently, including etymological information in the AND will certainly stimulate research in the language.

\section{Conclusion}

That a dictionary is an important resource for the preservation of a people's cultural heritage for posterity is indisputably true. In adding value to this function, the tradition of including etymological information in modern dictionaries has developed for a considerable time already. A dictionary should not just be a list of words with their definitions exemplified in context, but it should be more. An interest in knowing the origin of words has been established. This has added a new dimension to dictionaries, increasing their research value and in the process expanding their scope and uses. This article has tried to demonstrate the importance of giving etymological information in the $\mathrm{AND}$, in spite of certain challenges and problems.

\section{Endnotes}

1. $\mathrm{X}$ indicates the language from which $\mathrm{Y}$ is borrowing.

2. The Ndebele language has a noun class prefix system. The prefix morpheme $u$-is added to the adopted word.

3. These are now well-known Ndebele surnames. In conformity with the Ndebele phonological system, the Sotho consonant changes from $/ \mathrm{t} /$ to $/ \mathrm{d} / \mathrm{l} / \mathrm{k} /$ to $/ \mathrm{ng} /$ and $/ \mathrm{kg} /$ to $/ \mathrm{nk} /$.

4. Ndebele orthography does not allow the consonant $/ \mathrm{r} /$, so in all adopted words the letter $r$ changes to $l$.

5. Note that * represents a construction influenced by Shona. Although such constructions are still resisted in certain quarters, they are very prevalent. 


\section{References}

Chimhundu, H. (Ed.). 2001. Duramazwi Guru reChiShona. Harare: College Press.

Dube, C. 1993. Mzilikazi's History — The Logic. Letter. Moto Magazine 124: 3, May.

Hadebe, S. 2002. The Standardisation of the Ndebele Language through Dictionary-Making. D.Phil. Thesis. Harare/Oslo: University of Zimbabwe/University of Oslo.

Hadebe, S. (Ed.). 2001. Isichazamazwi SesiNdebele. Harare: College Press.

Hughes, A.J.B and J. van Velsen. 1954. The Shona and the Ndebele of Southern Rhodesia. London: International African Institute.

Khumalo, L. 2003. A General Introduction to Ndebele Grammar. Cape Town: CASAS.

Landau, S.I. 2001. Dictionaries: The Art and Craft of Lexicography. Second edition. Cambridge: Cambridge University Press.

Manuila, A. (Ed.). 1981. Progress in Medical Terminology. Basle: S. Karger.

Nyathi, P. 1994. Igugu LikaMthwakazi: Imbali YamaNdebele 1820-1893. Gweru: Mambo Press.

Rasmussen, R.K. 1977. Mzilikazi of the Ndebele. London: Heinemann.

Warburg, I. 1968. Notions of Correctness. Quirk, R. 1968². The Use of English: 347-359. London/Harlow: Longman. 